Short communication

\title{
Homeopathic potencies of Opium in alcohol dependence: exploratory open-label study
}

\author{
Ubiratan Cardinalli Adler ${ }^{1}$, Ana Elisa Madureira Padula1, \\ Amarilys de Toledo Cesar ${ }^{1}$, Maristela Schiabel Adler ${ }^{1}$, \\ José Carlos Fernandes Galduróz²
}

\begin{abstract}
(1) Associated researchers of the project "Translational study with innovative approaches for dealing with problems related to alcohol use, risk and dependence”. (2) Department of Psychobiology - Federal University of São Paulo, UNIFESP
\end{abstract}

\begin{abstract}
Background: The conventional pharmacological options for the treatment of alcoholism are limited, which led to the search for solutions in alternative or complementary medicine (CAM). Homeopathy is a CAM modality recognized as medical specialty in Brazil. According to the clinical experience of the early homeopaths, Opium was used to treat patients with alcohol dependence. Aim: to perform a preliminary assessment of the effectiveness and tolerability of fifty-millesimal potencies of Opium in the treatment of alcohol-dependent patients. Methods: exploratory, prospective, open-label trial, with pre-treatment measures as control. Confidence intervals were used to estimate the magnitude of the clinical differences. Results: a total of 14 patients were included, from which 12 were evaluated (intention to treat analysis - ITT). There was a significant reduction in the average daily alcohol consumption (-29.37 units of alcohol/day; $95 \% \mathrm{CI}=10.63$; 48.11) and in the severity of alcohol dependence, measured by the mean score of the Short Alcohol Dependence Data questionnaire $(-10.17 ; 95 \% \mathrm{CI}=4.12 ; 16.22)$. No serious adverse events were reported. Randomized controlled studies with larger samples are needed.
\end{abstract}

Keywords: alcohol dependence, homeopathy.

\section{Introduction}

Pharmacological interventions for the treatment of alcoholism approved by the United States FDA (Food and Drug Administration) include disulfiram and drugs that act on the reward system acamprosate and naltrexone. Disulfiram is an irreversible inhibitor of enzyme acetaldehyde-dehydrogenase, which breaks down alcohol in the acetaldehyde stage leading to accumulation of acetaldehyde in the organism each time alcohol is consumed, and a consequent ethanol-disulfiram reaction that discourages further consumption. It is potentially hepatotoxic and thus contraindicated in cases of liver cirrhosis, as portal hypertension may evolve to visceral bleeding induced by vomiting, during the ethanol-disulfiram reaction [1].

In recent reviews by the Cochrane Collaboration, acamprosate, a glutamate antagonist, and naltrexone, an opioid antagonist, showed superior efficacy to placebo in the treatment of alcoholism: for acamprosate, the risk of returning to drinking was $86 \%$ that of the placebo group (RR 0.86 ; 95\% CI $0.81-0.91$ ) [2] and for naltrexone, the risk of returning to drinking was $83 \%$ of the risk in the placebo group (RR 0.83; 95\% CI $0.76-$ 0.90) [3]. The risk of drinking any amount of alcohol did not exhibit statistical significance for naltrexone [4]. 
The authors considered glutamate and naltrexone to be effective strategies, "even though the sizes of treatment effects might appear moderate in their magnitudes, these should be valued against the background of the relapsing nature of alcoholism and the limited therapeutic options currently available for its treatment" $[4,5]$.

Limited conventional therapeutic options for the treatment of alcoholism motivate the search for solutions in alternative or complementary medicine (CAM), but studies evaluating CAM in the treatment of substance use disorders are still rare [6].

Homeopathy is a CAM modality recognized as medical specialty in Brazil. Homeopathic medicines are produced through sequential agitated dilutions in decimal (D), centesimal (C) or fifty-millesimal (Quinquagintamillesimal, Q or LM) potencies. Homeopathic preparations of opium were recommended by one of Hahnemann's closest disciple - Bönninghausen - to treat alcohol-dependent patients, as repeated doses of Opium could lead to a "sort of repugnance to spirituous liquors in general" [7]. However, this observation was never tested in clinical trials, which is also relevant on the grounds of the current knowledge about the pathophysiology of alcohol compulsion, since if ethanol stimulates the endogenous opioid activity of pleasure and reward, and an opioid antagonist inhibits it, perhaps Opium could homeopathically modulate the pleasure systems in the brain.

\section{Aim}

The present study sought to perform a preliminary assessment of the effectiveness and tolerability of fiftymillesimal (Quinquagintamillesimal, Q or LM) potencies of Opium in the treatment of alcohol-dependent patients.

\section{Methods}

Design: exploratory, prospective, open-label trial, with pre-treatment measures as control.

Patients: Patients of both sexes, aged between 18 and 65 years old, diagnosed with alcohol dependence according to DSM-IV-TR criteria. Exclusion criteria: dependence in remission; psychiatric medication, except for benzodiazepines and antidepressants; other dependence or substance abuse, except for nicotine.

Sample size: 14 patients were recruited for this exploratory study.

Intervention: The fifty-millesimal potencies of Opium were supplied in the form of sucrose pills, to avoid giving the patients medication in alcohol solution. They were prepared by fractionated grinding of the starting material, followed by sequential dilutions and shaking in ratio 1:50,000 for each step or potency. The first level of potency, LM1 or Q1, corresponds to a fraction of $5 \times 10^{-10}$ of the initially grinded opium (LM2 $=2.5 \times 10$ ${ }^{15}$, LM3 $=1,25 \times 10^{-20}, \mathrm{LM} 4=5.25 \times 10^{-24}$, and so forth) [8]. Initial dose was one globule on the tongue, three times a day, adjusted as needed. The medications were kindly donated by HN-Cristiano Pharmacy (Santana, São Paulo, Brazil).

Measurements: Primary effectiveness measure: pre-post treatment difference (week 1 - week 5) in daily alcohol consumption, measured in units of alcohol. Secondary end-points: difference in daily alcohol consumption between weeks 1, 5 and 7 and in the mean score of the Short - Alcohol Dependence Data (SADD) scale[9], between weeks $0,1,5$ and 7 . 
Procedures: After one week of pre-treatment observation (week 1), the patients were treated with fiftymillesimal potencies of Opium in weeks 2, 3, 4 and 5 (Q2, Q3, Q4 and Q5 potencies, respectively). This was followed by two weeks of recording consumption, without medication (weeks 6 and 7). Adverse events were recorded on each visit.

Statistical evaluation: Confidence intervals of $95 \%$ were calculated for the measurements, both individually and between periods, by taking two at a time. These intervals were obtained by Student's tdistribution due to the small number of individuals in the study. Unidirectional variance analysis (ANOVA) of repeated measures was used with last observation carried forward (LOCF) to compare assessments across four time-periods. When significant differences were identified, Bonferroni post hoc test was applied for multiple comparisons. The level of significance adopted throughout the study was $5 \%$ [9].

Ethics : The study was approved by the Research Ethics Committee of UNIFESP (CEP 0413/11).

\section{Results}

Between 09/14/2011 and 11/16/2011, 19 subjects were evaluated and 14 were included; 3 women (21.5\%) and 11 men (78.5\%), with average of approximately 15 years of alcohol dependence (15.2 \pm 11.8 years). Concomitant use of risperidone, fluoxetin, cocaine and complete remission of the alcohol dependence were reasons for exclusion. Two subjects, one man and one woman, abandoned the trial in the pre-treatment observation week, and were not included in ITT analysis. Nine patients completed the 7 weeks of the trial.

The weekly evolution of the mean daily consumption of units of alcohol and weekly SADD scale score, as well as the respective confidence intervals, are summarized in Table 1.

Table 1 - Weekly evolution of the daily consumption of Units of Alcohol and of the weekly SADD scale score, as well as the respective confidence intervals

\begin{tabular}{|l|l|c|c|}
\hline & & Units of alcohol & SADD weekly score \\
\hline & Intervention & Mean (95\% CI-limits) & Mean (95\% CI-limits) \\
\hline week 0 & Inclusion & - & $23.42(18.64 ; 28.20)$ \\
\hline week 1 & Observation & $74.1(43.31 ; 104.71)$ & $22.17(16.14 ; 28.19)$ \\
\hline week 2 & Opium 2 LM & $49.01(20.97 ; 77.05)$ & $18.75(11.93 ; 25.57)$ \\
\hline week 3 & Opium 3 LM & $47.43(13.01 ; 81.84)$ & $14.17(9.08 ; 19.26)$ \\
\hline week 4 & Opium 4 LM & $53.47(20.12 ; 86.82)$ & $14.33(9.18 ; 19.49)$ \\
\hline week 5 & Opium 5 LM & $44.64(11.88 ; 77.40)$ & $13.25(8.17 ; 18.33)$ \\
\hline week 6 & Observation & $38.44(4.64 ; 72.24)$ & $13.33(7.17 ; 19.50$ \\
\hline week 7 & Observation & $40.48(6.74 ; 74.22)$ & $15.08(9.11 ; 21.05)$ \\
\hline
\end{tabular}

The evaluation of the primary efficacy measure showed a clinically significant reduction in alcohol consumption between weeks 1 and 5, equivalent to one bottle of distilled alcohol less per day (-29.37 units of alcohol/day, 95\% CI=10.63; 48.11); this reduction was still significant after two weeks without treatment. 
The mean basal SADD score of patients in the sample was 23.42, thus placing the studied population in the "high dependence" category (score 1-9 = low dependence, 10-19 = medium dependence, 20-45 = high dependence [4]). During treatment with homeopathic Opium, the SADD score exhibited significant reduction to category "medium dependence" (SADD score from week 0 to week $5=10.17 ; 95 \% \mathrm{CI}=10.63 ; 48.11$ ). With the discontinuance of Opium, this reduction in the dependence score lost statistical significance, suggesting a reduction in the medication effect, due to reduction in the placebo effect and/or the specific effect of the medication. Adverse events (AE) reported during the 7 weeks are listed in Table 2. No serious AE was reported.

Table 2 - Reported adverse events during the 7 weeks of follow up

\begin{tabular}{|c|c|c|l|}
\hline Patient code & Age (yrs.) & Disease duration(yrs.) & \multicolumn{1}{|c|}{ Adverse Events } \\
\hline $\mathbf{1}$ & 25 & 13 & - \\
\hline $\mathbf{2}$ & 31 & 30 & $\begin{array}{l}\text { prolonged skin bleeding after external lesion, } \\
\text { acute diarrhea, tachycardia (patient with liver } \\
\text { disease) }\end{array}$ \\
\hline $\mathbf{3}$ & 35 & 20 & nausea, precordial pain, anxiety, headache \\
\hline $\mathbf{4}$ & 38 & 7 & - \\
\hline $\mathbf{5}$ & 41 & 7 & $\begin{array}{l}\text { polydypsia, myalgia, insomnia, nightmares, } \\
\text { anxiety, sadness }\end{array}$ \\
\hline $\mathbf{6}$ & 46 & 2 & - \\
\hline $\mathbf{7}$ & 46 & 10 & - \\
\hline $\mathbf{8}$ & 47 & 13 & (lost for follow up during week 1) \\
\hline $\mathbf{9}$ & 48 & 44 & - \\
\hline $\mathbf{1 0}$ & 52 & 14 & - \\
\hline $\mathbf{1 1}$ & 54 & 30 & - \\
\hline $\mathbf{1 2}$ & 55 & 5 & eye irritation with bleaching agent \\
\hline $\mathbf{1 3}$ & 57 & 8 & anxiety, bowel bleeding \\
\hline $\mathbf{1 4}$ & 59 & 10 & (lost for follow up during week 1) \\
\hline
\end{tabular}

Given the exploratory nature of the study, the small sample size and the absence of control group, no conclusion about the effectiveness of Opium in the treatment of alcohol dependence might be drawn, however, these results justify recruiting larger samples to perform for randomized controlled studies.

\section{References}

[1] Castro LA \& Baltieri DA. Tratamento farmacológico da dependência do álcool. Rev Bras Psiquiatr 2004; 26(Supl): 43-46

[2] Rösner S, Hackl-Herrwerth A, Leucht S, Lehert P, Vecchi S, Soyka M. Acamprosate for alcohol dependence. Cochrane Database Syst Rev. 2010;(9):CD004332. 
[3] Rösner S, Hackl-Herrwerth A, Leucht S, Vecchi S, Srisurapanont M, Soyka M. Opioid antagonists for alcohol dependence. Cochrane Database Syst Rev. 2010;12:CD001867.

[4] Raistrick D, Dunbar G, Davidson R. Development of a questionnnaire to measure alcohol dependence. British Journal of Addiction. 1983, 78:89-95.

[5] Johnson RA, Wichern DW. Applied Multivariate Statistical Analisys, 7. ed. 2008. Prentice Hall, Englewood Cliffs. 773 p.

[6] Dean AJ. Natural and complementary therapies for substance use disorders. Curr Opin Psychiatry 2005; 18(3):271-276.

[7] Bönninghausen CFM. Über die Philoposie. Allgemeine homöopathische Zeitung. Meyer V, Leipsig 1860; 60(22): 171-174.

[8] Hahnemann CFS. Organon der Heilkunst: aude sapere. 6.Aufl., hrsg. u. mit Vorw. vers. von Richard Haehl, Leipzig, Schwuabe, 1921, Heidelberg, Haug, 1988 § 246, 248, 270).

[9] Jorge MR \& Mansur J. Questionários padronizados para Avaliação do grau de Severidade da Síndrome de Dependência do Álcool. Jornal Brasileiro de Psiquiatria. 1986, 35(5), 287-292.

\title{
Potências homeopáticas de Opium na dependência do álcool: estudo exploratório e aberto.
}

\begin{abstract}
RESUMO
Contexto: as opções farmacológicas convencionais para o tratamento do alcoolismo ainda são limitadas, contribuindo para a busca de soluções na medicina alternativa ou complementar (CAM). A homeopatia é uma modalidade de CAM reconhecida como especialidade médica no Brasil. Na experiência clínica dos primeiros homeopatas, Opium era usado no tratamento de pacientes com dependência do álcool. Objetivo: avaliação preliminar da efetividade e da tolerabilidade de dinamizações homeopáticas de Opium no tratamento de pacientes dependentes do álcool. Métodos: estudo exploratório, prospectivo e aberto, com medidas pré-tratamento como controle. Intervalos de confiança foram utillizados para se estimar a magnitude das diferenças clínicas. Resultados: 14 pacientes foram incluídos e 12 avaliados (análise segundo a intenção de tratar- ITT). Houve uma redução clinicamente significativa no consumo médio diário de álcool ($29,37$ unidades de álcool/dia, $95 \% \mathrm{CI}=10,63 ; 48,11)$ e na severidade da dependência do álcool, medida pelo escore médio do questionário Short Alcohol Dependence Data (-10,17 pontos 95\% $\mathrm{CI}=4,12 ; 16,22)$. Não foram relatados ou observados eventos adversos graves. Os resultados justificam estudos maiores, randomizados e controlados.
\end{abstract}

Palavras-chave: dependência do álcool, homeopatia. 


\title{
Potencias homeopáticas de Opium en alcoholismo: estudio exploratorio abierto
}

\begin{abstract}
RESUMEN
Introducción: Las opciones farmacológicas convencionales para el tratamiento del alcoholismo son limitadas, por lo que se busca soluciones en las medicinas alternativas y complementarias (MAC). Homeopatía es una modalidad de MAC reconocida como especialidad médica en Brasil. Según la experiencia clínica de los primeros homeópatas, se utilizaba Opium en el tratamiento de pacientes alcohólicos. Objetivo: Realizar una evaluación preliminar de la efectividad y tolerancia de potencias cincuenta-milesimales de Opium en el tratamiento de pacientes alcohólicos. Métodos: Estudio prospectivo, exploratorio, abierto con medidas pre-tratamiento como control. Fueron utilizados intervalos de confianza para estimar la magnitud de las diferencias clínicas. Resultados: 14 pacientes fueron incluidos, de los cuales fueron evaluados 12 (intención de tratar). Se observó disminución significativa en el consumo diario de alcohol (-29,37 unidades de alcohol/día: IC95\%=10,63; 48,11) e en la gravedad del alcoholismo, medida como el promedio del puntaje en el Cuestionario Breve de Alcoholismo (-10,12; IC95\%= 4,12; 16,22). No fueron reportados efectos adversos graves. Son necesarios estudios aleatorizados controlados con muestras mayores.
\end{abstract}

Palabras clave: alcoholismo, homeopatía.

\section{(c)) BY-NC-ND Licensed to GIRI.}

Support: authors declare that this study received no funding

Conflict of interest: authors declare there is no conflict of interest. Opium potencies were provided by HN-Cristiano Pharmacy, under the responsibility of Cesar, AT (pharmacist), who has also donated Opium Q-potencies to the public health system of São Paulo.

Received: 02 March 2012; Revised: 21 March 2012; Published: 30 March 2012.

Correspondence author: José Carlos Fernandes Galduróz, Assistant Professor at the Department of Psychobiology, Federal University of São Paulo (UNIFESP), galduroz@psicobio.epm.br.

How to cite this article Adler UC, Padula AEM, Cesar AT, Adler MS, Galduróz JCF. Homeopathic potencies of Opium in alcohol dependence: exploratory open-label study. Int J High Dilution Res [online]. 2012 [cited YYYY Month dd]; 11(38): 19-24. Available from: http://www.feg.unesp.br/ ojs/index.php/ijhdr/article/view/548/556 